\title{
Confronting a Divided Past for a Shared Future: The Lieux de Mémoire of the Altab Ali Park in London
}

\author{
Dániel Vékony \\ Senior Lecturer, International Business School in Budapest \\ PhD Candidate, Corvinus University Budapest \\ Email: daniel.vekony@uni-corvinus.hu
}

This paper deals with the Altab Ali Park and its significance in regards to the Muslim community in the London borough of Tower Hamlets. Using Pierre Nora's concept of lieux de Mémoire, I would like to demonstrate how the Bangladeshi Muslim minority and the rest of the community of Tower Hamlets construct their collective memory through the transformation of the park. The article argues that the Altab Ali Park is in Pierre Nora's term a lieu de Mémoire with a multiple layers, which has been developed to enhance community cohesion in the Borough. The park itself contains further lieux de mémoire with clear messages against extremist secular and religious ideologies. This makes the park a symbol of multicultural coexistence in the district, which could help increase community cohesion through shaping the identity of the inhabitants of Tower Hamlets.

Keywords: social remembrance, collective memory, liex de mémoire, Muslims in Europe, identity

JEL codes: J15, I310, Z1

\section{Introduction}

The aim of this article is to demonstrate the attempt to shape the local identity of the London Borough of Tower Hamlets through the development of the Altab Ali Park. In the article, I argue that the Altab Ali Park is a multi-dimensional lieu de mémoire that the community consciously constructed to be a symbol of their collective past and also a tool to help their identity formation. The article includes two main parts: the first part gives a theoretical overview of the notion of collective memory, identity and Pierre Nora's lieux de Mémoire. The second part, after giving an overview of the history of the Tower Hamlets and the Park itself, will analyse the Park through the application Nora's concept of lieux de mémoire.

The paper applies an interpretivist approach, which requires the application of subjectivist or rather inter-subjectivist ontology. The article presents a number of theoretical approaches to collective memory and lieux de mémoire. Using these different interpretations will enable a wider approach to the topic. As a result, the paper is going to deal with reality as something that is dynamically constructed by society, not as an objective, static phenomenon. The epistemological approach will be aligned to these principles, as the paper will not only study facts and processes, but it will also explore the various meanings behind them. As far as axiology is concerned, based on these approaches, I need to point out that this paper is not 
value-free. The topic in question will be studied from a European perspective, and thus the findings of the paper should be interpreted in such a context too.

\section{Collective remembrance and the lieux de mémoire}

The term collective remembrance raises several questions. The ability of remembering is specific to individuals. Therefore, collective remembrance is established through the individuals comprising the given group. Referring to Halbwachs, Assmann (2013: 35-37) points out that remembrance and remembering are basically social terms that can only be exerted by living in society. Since an individual is only able to obtain memories and remember through existing within a certain group, any memories such an individual cannot get to are doomed to be forgotten.

Misztal (2003) highlights that the content of social memory is essential because it influences how members of a given group are related to other groups. The past formed about ourselves and our environment affects whether conflict or co-operation is dominant between the members of the two groups. Furthermore, Misztal draws our attention to the consequences of forgetting, too (Misztal 2003). Forgetting is the process of intentional or unintentional nonremembering (Fokasz - Kopper 2009).

We can contrast the process of forgetting outlined by Aristotle and Freud. According to Aristotle, forgetting is decay of imprints of past events and feelings in the mind, which implicates the passsive rather than the active attitude towards forgetting. Freud studied this process from another aspect. He highlighted that memories remain with us. According to this approach, forgetting is the process of suppressing memories by the ego. In this context, forgetting becomes an active action. We forget because we do not want to remember, either self-consciously or not (Forty 2001).

Cosidering the duality of forgetting and remembering, the models of both Aristotle and Freud contain elements that are relevant for our topic. For a British Muslim, the duality of forgetting and remembering implies both of the processes described above. The collective remembrance of second and third generation Muslims is becoming narrower also because in a British environment they are unable to receive such amount of memory information that they would get in a state having a Muslim majority. This phenomena confirms the Aristotelian logic on the one hand. On the other hand, British Muslim collective remembrance of the first generation immigrant contains vivid elements of the deprivation and the underdevelopment of the countries they had left. Therefore, it is not surprising that the new generations of Muslims growing up in Western-European cities sometimes have ambivalent feelings rather than pride towards their ancestors' countries of origin and cultures. In this situation the Freudian logic of forgetting comes into the foreground. It is possible that the second and third generation Muslims who were already born in Britain would have more memories from their ancestors' 
collective remembrance. However, several elements of the collective memory are simply not passed down as a result of the suppression owing to the children or parents' frustrations. ${ }^{1}$

As it was already mentioned, collective memory is a comprehensive set of memories that can be attached to a given group. Halbwachs (2000) points out that collective or group remembrance does not require the physical presence of the group at a given place. We can feel that we belong to a group anywhere, and the individual does not need to be physically present in the place where a certain community is located. This makes it possible to deal with collective memory in regards to British Muslims with an immigrant background in this study.

As for the ensuing British born Muslim generations, the process of remembering and collective remembering gets increalsingly fragmented. In regards to collective remembrance, Fokasz and Kopper (2009: 27) are on the opinion that in a given community young people simply adopt a certain past: As they grow up as parts of a given social group, they receive customs, stories and memories of that group. However, the British Muslims are somewhat different in this regard, because of their immigrant background. In this case, the young get the memories of their family on the one hand. However, this domestic environment only exists within a minority framework. And this minority setting is surrounded by majority society with its collective memory of several centuries, on the other hand. Therefore, WesternEuropean Muslims do not grow up in such an environment where religion and culture of their parents is omnipresent like an invisible fabric of their everyday life. Besides the parents' world, there is the different world of the majority society, which is often in conflict with the former one.

For this reason, Muslims, who were socialised in Europe and have an immigrant background, get a particular hybrid collective remembrance. Consequently, new, hybrid identities or a specific rootless state can emerge, where the experience of belonging to neither of the cultures becomes dominant. This latter phenomenon is called as the process of acculturisation by Roy (2004). In this process the individuals identify themselves with neither the parents' culture nor that of the reception society. Since they are unable to identify themselves with either of these cultures, a gap emerges in their idetity. Consequently, a global Islamic identity deprived of cultural elements can emerge fulfilling this gap. In such cases, the feeling of belonging to the group or nation represented by the parents becomes marginal. Besides, the attachment to the majority society will not gain ground either. As a result, the strongest tie is established towards the global ummah, the imaginary global community of the followers of Islam. All this can easily push young Muslims with insufficient knowledge in religious and politial issues towards radical groups.

We should not confuse collective remembrance with the historical past. Although collective remembrance consists of numerous historical events, the events of history always gain their place in collective remembrance through interpretations (Assmann 2013: 40-41).

Collective remembrance, also has an identity forming role. We remember the past to find answers to contemporary challenges, and to achieve certain social objectives. In order to

\footnotetext{
${ }^{1}$ Such memories might include the colonial past left behind, misery or an oppressing regime, which the parents are not willing to share with their children. Alternatively, suppression and the forgetting following these memories might be the result of the desire for integration into British society.
} 
realize these goals, we reach back to our collective memory, which means a relative rather than an absolute past in this context (Assmann 2013). This shows that in case of collective remembrance the aspect of the past develops consciously to a certain degree, upon which we guide and support our decisions in the present. At this point we are able to grasp the key difference between the historical past and the collective remembrance: the group uses the collective memory to consolidate and re-establish its own identity in order to enable itself to give appropriate responses to current challenges. Whereas the task of historians is to reveal the past with minute and scientific accuracy, collective remembrance requires neither scientific accuracy nor objectivity.

As Assmann points out (2013: 129) “...tradition is always sanctified with the aim of sanctifying a given community". This is in line with Nora's (1999) views, namely that the more noble our origin is, the more majestic it makes us, since it is through our past that we respect ourselves.

Therefore, collective memory is a certain kind of knowledge, which does not contain all memories and past events. It is only an extract that strengthens coherence within the group through determination of identity. At the same time, it gives us guidelines through past events to the challenges of the present in order to take our steps into the future with confidence. Referring to Durkheim, Pataki (2010) points out that the primary task of collective remembrance is to maintain the coherence and integration of the group. As the individual is able to survive in the world thanks to their memories, the group also needs its collective memory to keep itself together and thus step into the future. Therefore, if we want a community to have a steady and solid identity, we have to maintain and improve its collective memory. Consequently, minorities should not only remember their own roots. One of the conditions of their long-term survival is that they can find their worthy place in the surrounding society, too. In this way, new identities come into being with new hybrid collective memories attached to them.

As mentioned before, collective memory selectively sorts out the events of the past in order to maintain social coherence, and survival. Nevertheless, such selection from the happenings of the past is not necessarily reasonable and it also lacks the high demands of a historian (Gyáni 2012). However, it could be dangerous because a given group can recollect the past according to the values, interests and principles of the present in its collective memory. Therefore, collective remembrance plays a strange game with individuals. As Halbwachs (2000) puts it, collective remembrance lives in the individuals as some kind of immobile image, or rather a tabloid so that they can cover the past with the present. This provides the essence of the group's self-consciousness. However, this collective memory, which seems to be immobile, keeps changing as the group faces newer and newer challenges. As Pataki (2010) and Hobsbawm (1983) point out, collective memory and the related traditions can also be constructed or reconstructed arbitrarily. Power holders at any level are able to apply collective remembrance in order to achieve their own purposes. As a result a social group needs to be ready to question their collective memory if they are not satisified with their ruling elites and the narratives offered by them. This is what Pataki calls the risk of presentism (Pataki 2010). 
In parallel with the spread of mass information and new communication channels, Gyáni (2012) talks about excrescent collective memories. It is important to point out that in contemporary plural globalised societies collective remembrance and ultimately monopoly over history are in decline. Taking a look at various media outlets, it becomes clear that collective memories of various social groups and movements compete with each other. Numerous magazines, TV channels and Internet portals deal with the processing and revaluating of the past in certain aspects. These elements of so-called public history create a market for collective remembrance. This process started with the mushrooming of satellite channels, and later furthered with the growth of internet penetration in Western societies. Gyáni's concept covers Nora's theory in a number of aspects. However, Nora (2001) also adds that it is not only media that contributes to the eroding of the standard national collective memories. According to him, collective remembrance undergoes crises from time to time, and as a result of these crises collective memories are sometimes redefined in this process. ${ }^{2}$ Therefore, standard collective memory is questioned by the social groups that are in conflict with it or with the majority. For this reason, in a post-modern and pluralist society such as the British one, it is better to talk about competing collective memories, rather than a unified national collective memory. Thus, national collective memory is questioned by not only the subnational social groups. As one of the effects of the global information revolution, the challenge also comes from the transnational, global domain. As a result various groups of society have become potential consumers of local and global alternative historical narratives and thus alternative collective memories, too.

Besides, being a challenge, the alternative narratives offered by radical groups with links to global networks imply a threat, too. In many cases, these groups offer Western-European Muslim minorities interpretations of the past that are suitable to sharpen the conflict between the majority society and the Muslim minority. ${ }^{3}$ Such narratives mainly lay emphasis on the colonial past, post-colonial present and some measures of Western foreign policy that are disadvantageous to Muslims globally. It is a kind of post-colonial criticism of very often hypocritical Western foreign policy, ${ }^{4}$ which attracts solidarity based on the global ummah to turn Muslim minority groups against the majority society. Citing conflicts such as the

\footnotetext{
${ }^{2}$ As an example, Nora (2001) mentions the crisis of the French national collective remembrance in the 1970s, which was the first time the French society had faced the ambivalent heritage of the provincial past and the injustices committed against minorities such as the Jews in France. Consequently, French society started to form a critical attitude towards its past greatness. However, this required that certain groups of society question the contemporary consensus about collective remembrance.

${ }^{3}$ This phenomenon can be dangerous if the narratives are used to spread radical, suppressing ideologies. Regrettably, this happens in several cases. The online library of the Hizb ut-Tahrir, a radical organisation with the aim of restoring a Sunni Muslim caliphate is worth mentioning. On their website, numerous publications are available. These publications are made accessible on the World Wide Web in order to spread an alternative interpretation of Islam and of the past. (Hizb-ut-Tahrir n.d.)

${ }^{4}$ Hypocrisy in foreign policy is not necessarily a result of bad ethics. As Finnemore (2009: 74-76) points out, hypocrisy often means to be conscious about the reality and choose the least bad option from potentially bad decisions. Nevertheless, pointing out hypocritical foreign policy steps towards Israel and the Middle Eastern countries, for instance, can be a very useful tool for groups or individuals to further their influence within the Muslim community.
} 
Palestinian-Israeli one, the Iraqi or Afghan intervention, radical groups try to alienate receptive British Muslims from the majority society ${ }^{5}$ (Kepel 2004).

However, the simultaneity of rival narratives as well as the related social dispute imply an opportunity too, as these disputes may result in the emergence of new, more inclusive narratives and collective remembrances. As it has been already outlined, collective remembrance largely affects group identity. In this way, with social discussion on collective memory, not only group identities can change, but it may also be decided which narratives are accepted or not tolerated in order to ensure the coherence of given societies. In this way, interpretations and reinterpretations of the lieux de mémoire can actually contribute to the development of more adaptive and open societies.

Neuwirth and Plitsch (2001) suppose that the societal groups belonging to different religious sects possess different collective remembrances. Nevertheless, these subnational collective remembrances can make up a supra-collective remembrance. The question is whether different groups can find common points, through which they can establish a joint collective remembrance that is acceptable by the majority as well.

Summing up with Nora's (2001) thoughts, the lieux de memoire play a significant role in society, since in contemporary plural societies the communities of remembrance (millieux de mémoire) have been replaced by the places of remembrance (lieux de mémoire). Therefore, such places of remembrance are tools for individuals to connect to their own past, regardless of their political or cultural backgrounds.

The term lieux de mémoire has multiple meanings: it refers both to a place of memory, and a place of remembrance. However, lieux de mémoire does not only mean geographical place. This term can also refer to documents, events or even pieces of art such as a national anthem, a statue or a picture. Therefore, the lieux de mémoire include any and all symbols or pieces of art, places, and objects or notions that possess a symbolic value, which plays a role in the (collective) remembrance of a group (Nora 2001). A good example for this can be the oneminute silence held for heroes killed in military conflicts. While commemorating the wardead, different individuals can have different views on the battles themselves. Another example could be the different ways Ashura is commemorated by Muslims of different religious sects. ${ }^{6}$ Thus, lieux de Mémoire are "windows" to the collective memory or collective memories. What one sees though these "windows" depends on the background of the individuals looking through them. And in many cases, there are more than one, conflicting memories or narratives behind a lieux de mémoire.

At this point we can see that the lieux de mémoire is organically related to the term collective memory used by Assmann and Halbwachs. These places and events facilitate the given group to create the picture of itself, as well as determine and form the identity of the individual and a given group. Through the lieux de mémoire the individuals are able to consolidate their

\footnotetext{
${ }^{5}$ Hussain (2007) describes similar methods of radical Islamic groups in detail.

${ }^{6}$ The followers of the Shiite Islam remember the martyr death of Hussein imam in the Battle of Karbala on this day. This commemoration means remembering to a tragedy for the Shiites, which can have most extreme expressions in many cases (Fakhr-Rohani 2014). On the contrary, Ashura can be connected to far more positive memories for the followers of the Sunni Islam: in the tradition taken from judaism the Sunnis commemorate that Moses led the Jews out of Egypt (Katz 2007: 64).
} 
belonging and thus enhance social and group cohesion. In his study, Nora (1999) discusses the ceremonies of a society without ceremonies, the rites of a secularised society. However, the author of this study supposes that the term lieux de mémoire is not only specific to the modern secular societies. Each group possesses it, since places of pilgrimage, symbolic objects etc. can all be a lieux de mémoire.

The relevance of this topic arises from the fact that certain lieux de mémoire of majority societies are not always able to address the Muslim minorities. In many cases the lieux de mémoire of the majority society can be offensive for certain minority groups. Furthermore, in the case of former colonising countries, some lieux de mémoire related to the provincial past remind the Muslim and other minorities of former colonial backgrounds not only to the historical connections between the groups but also to the unequal and oppressive character of these relations. Therefore, lieux de mémoire like the British Museum can not only represent the former imperial greatness of Britain but it also implies the practice of the former British Empire to exploit and vanquish its colonial subjects. British citizens with Egyptian or Pakistani background are reminded not only about the richness of the British and human history by the amazing collection of the British Museum, but it also draws their attention to the historical process during which the British Empire vanquished the weaker non-European peoples and removed their heritage from their places of origin, to display these treasures as universal heritage of mankind in a foreign place. However, what serves as a proof of the former grandeur of the British Empire also highlights the weakness of the colonized. In this way the British Museum and similar lieux de mémoire remind members of the Muslim minorities of an aching point of their heritage. Thus the lieux de mémoire such as the British Museum may not fulfil the role of strengthening the relations between majority society and minorities with colonial roots, Muslims included.

This is why it is the responsibility of the various social groups and their representatives to establish such lieux de mémoire and find such narratives that connect rather than separate the social groups.

The application of lieux de mémoire seems to be a suitable tool for this purpose for several reasons. Through a lieux de mémoire the entire society's self-image can be formed (both the majority's and the minorities') by granting a dignified place in the national collective memory for every social group. For this an inclusive, supra-narrative ${ }^{7}$ is needed that would be acceptable for a wide spectrum of society. These "places" demonstrate towards the minorities that they have a worthy place in the society because numerous aspects connect their past to the majority. In this way, minorities can be proud of being part of their given society, because society is also proud that they comprise organic parts of it, too. Nevertheless, the key to longterm success is a conscious cultural-political strategy, which also takes minority needs into consideration upon the allocation of resources.

\section{Tower Hamlets: a short history}

\footnotetext{
${ }^{7}$ Described above by Neuwirth and Plitsch (2001).
} 
The Borough of Tower Hamlets has a long history of immigration and deprivation. Lying just the East of the historical London City walls, it has long been a periphery of the more well-off City throughout the centuries. The more relaxed and liberal attitude of British society resulted in consecutive waves of immigration of persecuted minorities to the British Isles and to London. As Kershen (2005) points out, the narrow streets, crowded and low-value accomodations of the district quickly became a magnet for immigrants with humble financial backgrounds. Tower Hamlets was desirable for its location, being close to the City and also the Docks. The former meant a close connection to the economic centre of the country, the latter proved to be a place of work and trade opportunities, which made the area of contemporary Tower Hamlets desirable for newcomers. As a result, by the $19^{\text {th }}$ century the area had a repuation of low quality housing, over-crowding and high rates of criminality. ${ }^{8}$ By this time, the borough became a bustling district, inhabited by a tangible Jewish population that had been fleeing the persecution of various countried on Continental Europe. Despite several attempts to ease the overcrowding, Tower Hamlets remained infamous in terms of being home to deprived communities in overcrowded accomodations after World War II as well. Social mobility meant leaving the district, a process many jewish families went trough during the past decades.

A new wave of immigrants started to arrive during the 1950s and 1960s from Bangladesh. This wave of immigration was driven by economic reasons. The first arrivals were mainly single male individuals who came to work in the lower sectors of the economy. Ansari (2004) and Goodhart (2014) describe this process of chain migration: in this phenomenon friendship and kinship plays a major role. The first arrivals recommend their relatives and trusted friends for their employers as further possible workforce to hire. This leads to the arrival of a group of people that are closely connected. Besides, since they know each other, they are able to provide accomodation to each other. Moreover, as these newcomers start to stand on their own feet, they do their best to get an accomodation near those people they know already. This process of ghettoisation was furthered in Tower Hamlets by the relatively low quality of housing. According to Aftab (2005), this process was one of segregation that was fueled by rational choice and economic necessity mainly. Down to the increasing number of family reunions during the 1970s, Tower Hamlets became again a very segregated community with a bleak social and economic outlook. As most of the Bangladeshis were from poor social and economic backgrounds, their persepctives for the future was even more limited. What happened in Tower Hamlets, fits a pattern of Muslim immigration in Western Europe: disadvantaged, poor and uneducated communities helped by chain migration were employed in low-paid positions that members of the local majority communities would not be willing to fulfill. As a result, a new underclass with immigrant and mainly muslim background was created during these decades. According to Zhou (1997), disadvantaged people with immigrant background have very small chances for social mobility, since low paid positions paired up with low levels of education make social mobility hard even for successive generations. This turned out to be the case with the Bangadeshi community in Tower Hamlets too. Even though the achievements in education of young Bangadeshis has been very

\footnotetext{
${ }^{8}$ The murders attributed to Jack the Ripper were also committed there (Kershen 2005).
} 
promising lately, this community is still considered relatively poor and segregated (Goodhart 2014).

The process of Bangladeshi immigration went parallel with the collapse of the British Empire, traditional industrial production and the decay of naval trade from these areas. Thus, the population of the borough went through multiple crises. The economic persepctives of the original inhabitants dramatically deterioratied. Besides, the presence of a high number of Bangadeshi people willing to take up virtually any job even for a low wage resulted in further conflict. If we approach this phenomenon from the world-systems theory of Wallerstein (1983), we could interpret the immigration of Bangadeshis as the recreation of the periperhy in the center. After the collapse of the colonial system, but before the wave of global offshoring that led to the emergence of virtual companies ${ }^{9}$ to ensure low costs of production, companies were happy to employ workers of immigrant background. But this also led to conflict with the working class of the majority society, who incearsingly felt that they were on the losing end of globalisation and immigration. ${ }^{10}$

This clash was even furthered when, the 1977 Homeless People Act opened the access for the Bangaldeshi minority to get council housing in Tower Hamlets(Goodhart 2014). Tensions led to the numerous attacks on the Bangladeshi community. Groups of far-right acitivists regularly attacked Bangladeshi houses and individuals. In the beginning, the Bangladeshi community passively endured these atrocities. ${ }^{11}$ However, following the murder of Altab Ali in 1978, protests were organized by the Bangadeshi community, which were also supported by the local left-leaning groups (Goodhart 2014). The Battle of Brick Lane is a good example of this new, more assertive attitude, during which the Bangladeshi community, with the help of anti-racist groups successfully defended their areas from white supremacist demonstrators. As a result, the white far-right groups were gradually evicted from the area. Besides, these events led to the relatively invisible local Bangladeshi community becoming a conscious social group with its own voice and identity (Leech 1994).

During the 1980s and 1990s, the number of atrocities decreased in the borough. In the present day, the Bangadeshi community plays a significant role in a truly multicultural Tower Hamlets. As the Bangaldeshi population take up approximately $34 \%$ of the overall population of the borough, it has become a community every local politician needs to take into account (Aftab 2005).

The Bangadeshi community is organised according to two main dimensions. The first one is based on Bangadeshi ethnic identity and is rather nationalistic and secular. Movements such as the Awami league play a major part in this domain (Aftab 2005). The second one is based on religious terms. In this case the national identity plays only a secondary role next to a global Islamic identity. Islamist movements such as the Jamaat-i-Islami are opposed to the nationalist and secularist agenda, which results in conflict within the Bangladeshi community

\footnotetext{
${ }^{9}$ Virtual companies are corporations that offshored and outsourced most of their production activities and only keep their core design and R\&D activities in their places of origin (Rosecrance 1996).

${ }^{10}$ The eventual advent of virtual companies and global-scale off-shoring meant that the opportunities of both Bangladeshi and majority working-class individuals deteriorated in the last decades. This did not help ameliorate the conflictual situation between the two sides.

${ }^{11}$ As shown later, the murder of Altab Ali was a turning point in this regard.
} 
itself. The main conflict is between the secularist supporters of the Awami league and the Jamaat-i-Islami, whose leaders are opposed to Bangladeshi indepenence and were allegedly taking part in atrocities against the Bangadeshi population during the 1971 conflict (Hossain 2010). The East London Mosque, one of the main Muslim religious and cultural centres of Tower Hamlets, is supposedly under the control of this Islamist movement (Hussain 2007).

\section{The history of Altab Ali Park}

The Park has a chequered history. It used to be the site of the White Chapel, the eponym of the surrounding area in the Borough. However, this building was rather short-lived. ${ }^{12}$ It was later rebuilt as St Mary Matfelon church in 1329. Richard Brandon, the executioner of king Charles, who beheaded the king in 1649, is buried in the church's grounds. This attaches the memory of the short-lived republican Britain to the square. During the past centuries, the church underwent a number of renovations and restructurings that changed its appearance. In 1940, the church was damaged by Luftwaffe bombings. The remains of the church became a playground for local children and a makeshift shelter for the homeless. The condition of the derelict building further deteriorated when it was struck by lightning. In 1952, the church building was pulled down. 14 years later, the former churchyard was opened to the public as a municipal park (London Remembers n.d.).

In 1978, Altab Ali, a Bangladeshi mechanic in a nearby sweatshop, who recently moved to the UK, was murdered in the churchyard park on his way home. His murder sparked protest from the Bangladeshi community that already endured years of racist attacks. Altab Ali's murder thus became a turning point for Tower Hamlets and the Bangladeshi community. Before the killing took place, racist attacks on Muslim immigrants were common in this part of London. The murder of Altab Ali managed to galvanize the community and other parts of society also sided with the Bangladeshi minority opposing the racial supremacist elements of the district. Protesters marched from Tower Hamlets to Downing Street with Ali's coffin as an act of defiance. As a result, the backlash of the murder was the starting point of the eviction of far-right and racist groups from the neighbourhood. Consequently, the Bangladeshi community managed to assert not only their position locally, but also their identity as an integral part of Tower Hamlets. Soon after the murder took place, the Park was renamed Altab Ali Park in 1979 (Keith 2005).

\section{A park with various symbols: the Altab Park as a lieux de mémoire of Tower Hamlets}

Altab Ali Park was developed with the intention to emphasise the shared heritage of the community of the London Borough of Tower Hamlets, and as a result to foster much needed community cohesion. The park contains a number of different objects of remembrance that act as lieux de mémoire. Together, they represent the colourful heritage of the borough and as a result help to create a unified local identity, which people living in Tower Hamlets could attach to.

\footnotetext{
${ }^{12}$ It stood between 1250 and 1286 only.
} 


\subsection{The memory of Altab Ali}

A possible reason why Altab Ali became such a symbolic figure is that he was an average Bangladeshi immigrant of 25 years of age, when he was murdered in 1978 in the Park grounds. He had recently arrived from Bangladesh and was employed in a sweatshop nearby as a mechanic. He represented many things that were characteristic of the contemporary Bangladeshi community. He was relatively young, he worked on the margins of the economy. Sweatshops were usually run by local Bangladeshi businesspeople, who employed fellow Bangladeshis in accordance with the logic of chain migration. The murder of Ali was not a lone incident, rather it was the last straw. Thus, this racially motivated killing triggered a fundamental change in the attitude of the Bangladeshi community. Their attitude changed from being defensive to assertive, which manifested in the marches organized after the murder had taken place.

The lieux the mémoire of Altab Ali is open to number of interpretations. Apart from a reminder of the murder and the racial violence itself, it is a place to remember the beginning of the coming of age of a local public British-Bangladeshi identity of Tower Hamlets. It is also a place to remember the end of the terror of white supremacist groups in the district. As a result, the park serves as not only as a reminder of the violent past of the Borough. It is also a symbol of the will for a more cohesive and harmonious coexistence of communities who united against the far-right movements terrorising the Bangladeshi minority areas and the Borough as a whole. As such, the park is a symbol of coming together against hatred, a place for rest and reflection that brings different communities of the borough together.

\subsection{The entrance of the Park}

The entry gate of the park is itself a symbol of the multicultural nature Tower Hamlets. The gate is the work of Welsh artist and blacksmith David Petersen. The old churchyard's gateposts serve as the foundation of the arch of the gate that has a hybrid design with direct references both to the European Christian tradition and also to Bengali architecture (Alexander et al. 2015). This gate is itself a statement of lieux de mémoire. It serves as a tool to connect the past with the present and as a result create a space of remembrance, attachment and identity. It is a gateway to an area that accommodates relics of the indigenous English heritage and the recently settled Bangladeshi community's past too. As it combines elements from both cultural backgrounds, it delivers the message of harmonious coexistence in a shared space of Tower Hamlets. By entering through this gate, one enters into a symbolic shared space of communities of different backgrounds. Still the gate itself symbolises how formerly distant cultures can create a harmonious space together.

\subsection{The ruins of the Church}

The developers decided to leave the foundations of the church visible and incorporated it to the pavement of the park. As a result, the shape of the former church building is clearly 
visible. Besides, some other objects of remembrance were also restored from this long-gone past of the area: tombstones and a sarcophagus remind the visitors that this park was not only a place of worship, but also a place where people were buried. These objects of remembrance serve as a reminder of the Christian heritage of the area and they also honour those generations who contributed to the history of the district.

\subsection{The replica of the Shaheed Minar}

In one corner of the park a replica of the Shaheed Minar was erected in 1999. The original Shaheed Minar is monument in Dhaka, Bangladesh, but there are a number of replicas over the world. It was erected to commemorate the struggle of the Bengali language movement under unified Pakistani rule (Alexander et al. 2015). Thus, the original Shaheed Minar is a monument and as such, a lieu de mémoire with already multiple symbols attached to it. As mentioned above, it is a symbol of the struggle for the usage of Bengali language, since the Pakistani government wanted to marginalise this language in favour of Urdu, which was one of the main reasons of the struggle for independence in Bangladesh. As such, it also became a symbol of the struggle for Bangladeshi independence from Pakistan. As a result, it invites visitors to remember the victims of these interrelated struggles. Thus, the Shaheed Minar has become a monument for Bengali nationalism.

The replica of the Shaheed Minar is a very strong statement of "long distance" nationalism of the Bangaldeshi community of Tower Hamlets (Alexander et al. 2015). Every February, locals with Bangladeshi roots gather in the Park to commemorate the victims of the struggles mentioned earlier. However, the monument in East London also has its own, local symbolic meaning as well. Being a monument for Bengali nationalism, it has a distinct message for the local Bengali community. Since Islamist movements sided with the Pakistani government during the Bangladeshi struggle for independence, and were involved in atrocities against the local population, the Shaheed Minar is also a lieu de memoire in support of a secular, nationalistic Bangladeshi identity in opposition to universalist Islamist ideologies. This sheds light on the reasons behind the fierce opposition against the construction of the East London Shaheed Minar monument not only from white supremacist elements, but also from Islamist religious groups with a Bangladeshi background (Keith 2005: 145-146). Thus, the controversies behind the monument reveals the social cleavages within the Bangladeshi community and also between them and the majority society as well.

What we can see here is a conscious effort from one part of the Bangladeshi populace to position themselves according the ethnic or national lines using a secular lieu de mémoire on the site of another lieu de Mémoire. And thus, a struggle for power and for the ability to define the identity of the Tower Hamlets Bengali community comes to the surface. Many in the community would like to establish an identity based much more on religion than on nationalistic lines. On the other hand, one can see that the ethnic or nationalistic identity of the Bengali diaspora is still strongly present in the community. Taking Roy's (2004) theory on acculturation into account, we can see a struggle to preserve the nationalist heritage and the secular Bangladeshi identity in favour of a global religious identity with considerable influence. As for now, the two exist side-by-side. 
According to Sassen (2012), global cities such as London have become polarized around disadvantaged and powerless communities with immigrant background on the one hand and the powerful group embedded in global economic networks on the other hand. The Altab Ali Park is also a lieux de mémoire of what Sassen calls the cross-border space to which the Bangladeshi community connects. The debate about the construction of this lieu de mémoire within the Bangladeshi community reveals that the global space to which the Bangladeshi community connects are conflictual and thus multidimensional. By trying to emphasise a secular past, powerful figures of the local Bangladeshi community used tools of forgetting and remembering to influence the self-image of the local community. Here an attempt not to remember can be seen. By not giving space to the religious heritage of the local Muslim communities, secular Bangladeshi community leaders may hope the religious aspect of their identity could be downplayed or controlled. As such, the Shaheed Minar, and a lack of any reference to Islam in the Park could also be interpreted as a denial of space for the Islamist movements active in the borough. Thus, here the Freudian aspect of forgetting through suppression could be applied.

\subsection{Refurbishment of the Park}

The Park obtained its current form during a refurbishment campaign in the run-up to the 2012 Olympics in London. The development of the Park was conducted by the Museum of London. The developers wanted to create a space that enables both leisure and reflection on the past. Besides excavating and making the ruins of the old church accessible, they also created an open-air museum. Local schoolchildren from various backgrounds were invited to take part in the excavation and also to bring objects that were later put on display in the park (Museum of London Archaeology 2011).

The redevelopment of the park stands in contrast to the British Museum, mentioned above. The developers attempted to create a shared space that is inclusive for every community of the borough. By creating a tiny open-air museum with past and contemporary content, they attempted to create a bridge between past and present communities. This is supposed to strengthen the feeling of belonging and to create a new hybrid local identity, while the reflection on the past is not downplayed. Besides, since the Park is situated on the edge of the City of London and Tower Hamlets, it also acts as a gateway to both places. This gateway is now a tool to unite the two districts instead of separating them, as has it happened in the past.

\section{Conclusions}

The Borough of Tower Hamlets has a long history to accommodate communities from diverse backgrounds. Its past (and present) is also a story of poverty. Since deprivation goes hand in hand with fierce competition for scarce resources, it is not surprising that even the recent history of this part of London is marred by violence between communities. The Altab Ali Park serves as a place to heal the wounds of some of these past conflicts, and to give a clear statement on the identity of the borough. 
The information boards placed in the Park tell the Story of Altab Ali, of the Church that was standing there and was originally called White Chapel, and of the Shaheed Minar. By commemorating the old Christian and the contemporary Bangladeshi history of the area, the park serves as a place of remembrance. Visitors to the park are reminded of the Christian heritage, of World War II, and of the Bangladeshi community's struggles both in the UK and in Bangladesh. This park is a local lieux de mémoire with a truly global reach. Besides its function to enhance multicultural harmony, it is also a clear statement of secular Bangladeshi identity. This is also an indirect statement against the universalist Islamist ideology that has a very powerful presence in the area. As such, one of main purposes of the Park is to secure a dignified place for the Bangladeshi identity in Tower Hamlets.

The Park also serves as a call for tolerance and a call for hybridity. As such, it is a tool to shape collective memory of the local community by a number of lieux de mémoire within a lieu de mémoire itself. By acknowledging the past struggles of the Bangladeshi community, the park is a symbol of the rejection of extremist movements and the acceptance of a secular and multicultural cohabitation on Tower Hamlets. In this way the Park is a tool to shape the collective memory of local communities and to create a local identity that is inclusive towards various communities of the borough. As such, it could serve to promote tolerance and acceptance between the various communities of the borough. Local communities use the Park not only for leisure, but also for political activism. ${ }^{13}$

As noted earlier, the lieux the mémoire are windows on the past, through which we could connect to our heritage. It is also clear that these "windows" could also promote certain narratives that shape the collective memory of communities. As such, the Altab Ali park is an example, when certain millieux de mémoire create lieux de memoire to promote their narrative and identity. However, because of the characteristics of the lieux de mémoire, this park still offers a number of narratives to members of various communities. The Shaheed Minar for instance has a different meaning for a secular and a non-secular Bangladeshi individual. Besides, the visible ruins of the church can have diverse meaning for Christian and Muslim individuals.

Nevertheless, the Altab Ali Park is a good example of how local communities try to use public spaces to shape the identity of their communities and promote harmony and cohesion.

In its current form, however, the park still looks incomplete. Memories of the Huguenot and the Jewish population are nowhere to be found in the park as of today. However, the idea of collective memory and the lieux de mémoire serve contemporary goals. The past in this case is only used as a tool for certain present goals. In this light, it is no surprise that stories of minority groups of elder days have not been told in the Altab Ali pPrk. The regular remembrance of the murder of Altab Ali is a kind of invented tradition that was created in order to ensure a dignified position of the minority Bangadeshi community in this part of London and to serve as a ritual that strengthens the local Bangladeshi identity (Hobsbawm 1983). With this, the Bangladeshi community of Tower Hamlets has taken its first steps in their journey that will take them even further from their homeland.

\footnotetext{
${ }^{13}$ Demonstrations were held against the killing of certain individuals in Bangladesh because of their secular views in the Park in 2016.
} 
Down to its position, the Altab Ali Park acts as a gateway to Tower Hamlets for those who enter into the borough from the City of London. And as such, with its multiple lieux de mémoire, it is a symbol of Tower Hamlets itself: a multicultural and deprived neighbourhood, that tries to learn from its past in order to overcome the contemporary challenges and to step into a more prosperous and harmonious future. Only time will tell, whether the colourful and sometimes conflictual memories of communities will be able converge to create a unified local identity that conveniently fits into the national one as well.

\section{References}

Aftab, I. (2005): The Spatial Form of Bangladeshi Community in London's East End. In: Van Nes, A. (ed.): Space Syntax 5th International Symposium, Delft University of Technology Amsterdam: Techne Press, pp. 129-144.

Alexander, C., - Chatterji, J., - Jalais, A. (2015): The Bengal Diaspora: Rethinking Muslim migration. London and New York: Routledge.

Ansari, H. (2004): 'The Infidel Within' - Muslims in Britain since 1800. London: Hurst \& Company.

Assmann, J. (2013): A kulturális emlékezet [The Cultural Remembrance]. Budapest: Atliantisz kiadó.

Fakhr-Rohani, M.-R. (2014): Ashura. In: Morrow, J. A. (ed.): Islamic Images and Ideas: Essays on Sacred Symbolism. Jefferson, North Carolina, USA: McFarland \& Co.

Finnemore, M. (2009): Legitimacy, Hypocrisy, and the Social Structure of Unipolarity: Why Being a Unipole Isn't All It's Cracked Up to Be. World Politics 61(1): 58-85.

Fokasz, N., - Kopper, Á. (2009): Szenzációk kettős szerepben. Az emlékezés helyei és miliői a médiában [Stuns in different dressing. Places and millieux of remembrance in the media]. Szociológiai szemle (4): 25-42.

Forty, A. (2001): Introduction. In: Forty, A. - Küchler, S. (eds): The Art of Forgeting. Oxford, New York: Berg Publishers.

Gyáni, G. (2012): Nemzet, kollektív emlékezet és public history [Nation, collective memory and public history]. Történelmi szemle 54(3): 357-375.

Goodhart, D. (2014): The British Dream. London: Atlantic Books.

Halbwachs, M. (2000): A kollektív emlékezet és az idő [Collective memory and time]. In: Felkai, G. -Némedi, D. - Somlai, P. (ed.): Szociológiai irányzatok a XX. század elejéig [Socioligical trends until the early 20th century]. Budapest: Új Mandátum kiadó.

Hasan, R. (2010): Multiculturalism Some Inconvenient Truths. London: Politico.

Hizb-ut-Tahrir. (n.d.): Books, http://www.hizb-ut-tahrir.org/index.php/EN/books/, accessed 20.01.2016.

Hobsbawm, E. (1983): Inventing Traditions. In: Hobsbawm, E. - Ranger, T. (eds): The Invention of Tradition. Cambridge, UK: Cambridge University Press, pp. 1-15. 
Hossain, M. (2010): Bangladesh. In Rubin, B. (ed.): Guide to Islamist Movements New York, London: M. E. Sharpe

Hussain, E. (2007): The Islamist. London: Penguin Books.

Katz, M. H. (2007): The Birth of The Prophet Muhammad: Devotional Piety in Sunni Islam. London: Routledge.

Keith, M. (2005): After the Cosmopolitan? Multicultural cities and the future of racism. London and New York: Routledge.

Kepel, G. (2004): The War for Muslim Minds. Cambridge, MA, USA: The Belknap Press of Harvard University Press.

Kershen, A. J. (2005): Strangers, Aliens and Asians: Huguenots, Jews and Bangladeshis in Spitalfields 1660-2000. London and New York: Routledge.

Leech, K. (1994): Brick Lane 1978. London: Stepney Bks.

London Remembers. (n.d.): Ghost building: St Mary Matfelon, http://www.londonremembers.com/memorials/st-mary-matfelon, accessed 08.02.2015.

Misztal, B. A. (2003): Theories of Social Remembering. Maidenhead: Open University Press.

Neuwirth, A. - Plitsch, A. (2001): Crisis and Memory: Dimensions of their relationship. An introduction. In: Neuwirth, A. - Plitsch, A. (eds): Crisis and memory in Islamic societies. Würzburg, Germany: Ergon Verlag.

Nora, P. (1999): Emlékezet és történelem között - A helyek problematikája [Between Memory and History: Les Lieux de Memoire]. AETAS Történettudományi Folyóirat http://www.aetas.hu/1999 3/99-3-10.htm, accessed 05.07.2015.

Nora, P. (2001): General Intruduction. In: Nora, P. (ed.): Rethinking France: Les lieux de mémoire. Chicago: University of Chicago Press.

Pataki, F. (2010): Kollekítv emlékezet és emlékezéspolitika [Collective memory and politics of remembrance]. Magyar Tudomány (7):778-798.

Roy, O. (2004): Globalized Islam - The search of a new ummah. New York: Columbia University Press.

Rosecrance, R. (1996): The Rise of the Virtual State: Territory Becomes Passé. Foreign Affairs 74(4).

Sassen, S. (2012): When the center no longer holds: Cities as frontier zones. Cities 34 :67-70.

Wallerstein, I. (1983): A modern világgazdasági rendszer kialakulása: A tökés mezögazdaság és az európai világgazdaság eredete a XVI. században [The Modern World-System, vol. I: Capitalist Agriculture and the Origins of the European World-Economy in the Sixteenth Century]. Budapest: Gondolat Kiadó.

Zhou, M. (1997): Segmented Assimilation: Issues, Controversies, and Recent Research on the New Second Generation. The International Migration Review 31(4): 975-1008. 